\title{
EQUiLIBRIUM
}

Quarterly Journal of Economics and Economic Policy

2016 VOLUME 11 ISSUE 2, June

p-ISSN 1689-765X, e-ISSN 2353-3293

www.economic-policy.pl

Łapińska, J. (2016). Determinant Factors of Intra-Industry Trade: the Case of Poland and Its European Union Trading Partners. Equilibrium. Quarterly Journal of Economics and Economic Policy, 11(2), 251-264. DOI: http://dx.doi.org/10.12775/ EQUIL.2016.011

Justyna Lapińska*

Nicolaus Copernicus University, Poland

\section{Determinant Factors of Intra-Industry Trade: the Case of Poland and Its European Union Trading Partners}

\section{JEL Classification: $C 12 ; C 51 ; F 14$}

Keywords: intra-industry trade; country-specific determinants; Poland, European Union

\begin{abstract}
This study has investigated the country-specific determinants of intraindustry exchange between Poland and its European Union trading partners during the time period 2002-2011. The analysis of the factors determining the Polish bilateral intra-industry trade with European Union countries applied an econometric model for panel data. As follows from the research, the intensity of intraindustry trade is dependent on numerous factors. The factors that exert a positive impact on the development of intra-trade exchange include the participation of processed products in bilateral trade between Poland and UE states, the intensity of trade with specific countries as well as the size of a partner country measured by its GDP per capita. Increases in the intra-trade turnover are also facilitated by EU membership and by the fact that Poland's trade partners use a similar language, belonging to the group of the Slavic languages. The intensity of intra-trade exchange is weakened by the degree of the imbalance of trade turnover between trading partners, geographical distance that separates trading partners and significant differences in the size of trading partners' GDPs.
\end{abstract}

(C) Copyright Institute of Economic Research

Date of submission: June 8, 2015; date of acceptance: January 14, 2016

* Contact: justlap@umk.pl, Nicolaus Copernicus University, Gagarina 13a, 87-100 Toruń, Poland 


\section{Introduction}

Intra-industry trade, also called two-way trade, consists in simultaneous importing and exporting products (including assemblies, subassemblies and components) coming from the same industry, which are close substitutes in the sphere of consumption, production, or in both of these areas (Grubel \& Lloyd, 1975, p. 35). Trade cooperation between European Union member states is based mainly on the intra-industry trade, which forms the substitutability of economies (see Fitzová \& Žídek, 2015, pp. 36-50). Trade flows develop particularly well between the countries that are similar due to their relative resources of production factors, use similar production technologies, and possess a similar structure of buyers' preferences.

The intensity of intra-industry trade is dependent on numerous factors. They are generally divided into two categories. The first is the countryspecific determinants. These are the characteristics of the economies of trading partners involved in the exchange. The second group includes industry-specific determinants, i.e., the characteristics of the industry, in which the exchange of products is realised. The purpose of this study is to identify country-specific determinants impacting the intensity of intraindustry trade in Poland's trade turnover with EU countries.

\section{Country-Specific Determinants - Literature Review}

Previous theoretical and empirical works confirm that the intensity of intraindustry trade depends on numerous factors. The major factors include the size of the economies engaged in the exchange measured by the size of their GDP. The greater the size of the market of trading countries, the stronger their intra-industry trade. Stone and Lee (1995, pp. 67-85) argue that large markets are conducive to conducting intra-industry trade, mainly due to greater possibilities of extending production characterized by increasing economies of scale. However, there are some empirical studies that do not confirm the relationship between the market size and the intensity of intra-industry trade. Such a relationship was not confirmed by Černoša (2002, pp. 355-370), who examined the impact of differences in the size of partner countries on intra-industry trade based on the example of Slovenia and the Czech Republic. Differences between partners' GDP are also important. The smaller they are the more intense intra-industry trade is. The results of the research conducted by Kim and Oh (2001, pp. 401-406) 
confirm that the above relationship is valid for both developed countries and developing ones.

The set of potential factors contributing to the development of intraindustry trade also includes a high level of gross domestic product per capita as well as small differences between GDP per capita of trading countries. The importance of this type of factors in increasing the intensity of intra-industry trade is confirmed by, among others, Loertscher and Wolter (1980, pp. 280-293), and Thorpe and Zhang (2005, pp. 231-247).

An important factor in promoting the development of intra-industry turnover is trade liberalization. Tariff and non-tariff barriers by restricting access to foreign markets affect both intra-industry and inter-industry trade. However, as proved by the theory of intra-industry trade, strengthening trade protection impacts relatively more intra-industry trade than interindustry trade. This is so because goods exchanged within intra-industry trade are close substitutes, so they have a pretty high price elasticity of demand. The factor that is associated with the process of removing barriers to trade and also promotes the development of intra-industry trade is economic integration. The importance of economic integration for increasing the intensity of intra-industry trade is associated not only with the reduction of barriers to trade, but it also results from the fact that the integration grouping includes mostly countries with a similar level of economic development. The results of empirical studies (see, for instance, Sharma, 2004, pp. 1723-1730; Wakasugi, 2007, pp. 26-39, Foster \& Stehrer, 2011, pp. 385-409) show that under the conditions of imperfect competition and product differentiation, processes of integration and trade liberalization exert a positive influence on the development of intra-industry trade.

The degree of the intensity of trade exchange is significantly affected by the geographical distance separating trading partners. Geographical distance, mainly due to transport costs, constitutes a factor limiting the development of both intra-industry trade and inter-industry trade. However, it has a stronger impact on the development of intra-industry trade. Differentiated products, which are the subject of this type of exchange are characterized by a high price elasticity of demand and, therefore, are relatively more sensitive to changes in costs and prices than goods traded within inter-industry trade. A negative correlation between the geographical distance separating trading partners and the intensity of their mutual intra-industry trade exchange is confirmed by empirical studies carried out, among others, by Stone and Lee (1995, pp. 67-85), Cieślik (2000), Leitão and Shahbaz (2012, pp. 505-512). Determinant associated with the two-way exchange related to geographic proximity is the existence of a common border. The results of the empirical research conducted by Balassa and Bauwens (1988, 
pp. 1421-1437) and Ekanayake (2001, pp. 89-112) confirm that having a common border with a business partner impacts positively the development of mutual intra-industry trade.

A factor supporting the development of intra-industry trade is also a cultural community of partners, and, in particular, the common or similar language, national identity, tradition, or history. Zielińska-Głębocka (1991) argues that cultural ties, mainly due to the low barriers to conducting marketing activities in foreign markets (a common language makes it easier to communicate), low transaction costs and the similarity of the structure of demand facilitate significantly conducting intra-industry trade.

Empirical studies attempt to verify other factors. Zhang and Clark (2009, pp. 325-356) focused on the level of innovation of the economies of trading countries. They assume that the nature of products manufactured in trading countries depends on the degree of the use of innovative technological processes. An important source of innovative technological processes, are also foreign direct investments, which also constitute a determinant of intra-industry trade. However, the direction of the impact of FDI on bilateral exchange of similar products cannot be defined explicitly. On the one hand, they may contribute to the development of intra-industry trade. As a matter of fact, they create opportunities for technological modernization of the economy, industrial development and production of differentiated goods with a high degree of processing. The positive relationship between foreign direct investment and intra-industry trade is confirmed by the results of empirical studies carried out by such researchers as Xing (2007, pp. 685-700), or Salamaga (2012, pp. 113-127). However, on the other hand, as noticed Markusen and Vanables (1996), foreign direct investment can also be a substitute for foreign trade and thus limit the development of intraindustry trade.

Other factors determining the level of intra-industry trade between countries are a high share of goods processed in mutual trade turnover and a considerable intensity of trade relations between trading partners. Byun and Lee (2005, pp. 1-29) and Ekanayake (2001, pp. 89-112) argue that these factors significantly contribute to the development of intra-industry trade. Empirical studies conducted by Leitão (2011, pp. 186-190) show, however, that a negative impact on the intensity of intra-industry trade is exerted by the existence of trade imbalance. 


\section{Research Methodology}

In order to identify the factors determining Poland's intra-industry trade with EU member states an econometric model for panel data was constructed. The values of the Grubel-Lloyd index were taken for the dependent variable and were calculated according to the following formula (Grubel \& Lloyd, 1975):

$$
I I T=\frac{\sum_{i=1}^{n}\left(x_{i}+m_{i}\right)-\sum_{i=1}^{n}\left|x_{i}-m_{i}\right|}{\sum_{i=1}^{n}\left(x_{i}+m_{i}\right)},
$$

where:

$x_{i}-$ the value of exports of the industry $i$,

$m_{i}-$ the value of imports of the industry $i$.

Bilateral intra-industry trade indices were calculated for Poland's trade with individual countries of the European Union in the years 2002-2011, and for the three-digit product groups they were categorized according to the Standard International Trade Classification.

The study covered 26 of Poland's trade partners who were member states of the European Union in 2011. The size of the economies of trading partners measured by their GDP and an indicator of the relative difference between GDP of Poland and its trading partners were taken as potential explanatory variables. The set of explanatory variables also included variables describing the saturation level of the economies of trading partners and foreign capital, share of processed products in the mutual trade turnover of a pair of countries. The impact of geographical distance between countries expressed in the number of kilometres between their capital cities was also taken into account. In addition, the fact that Poland's trade partners use a similar language, i.e., belonging to the Slavic languages group was considered. Moreover, the impact of being a European Union member state on the increase of the intensity of intra-industry trade was examined. To this end, two dummy variables ( $E U$ and $L A N G$ ) were introduced into the model.

The dependent variable IIT is an index taking on values from the interval $[0 ; 1]$. The higher the value, the greater the share of intra-industry trade in trade volume. A logit transformation of the dependent variable was performed. In that way we obtained a dependent variable in the form of the $\ln (I I T / 1-I I T)$, and this dependent variable's values are contained in the interval $(-\infty ; \infty)$. This eliminated the possibility of obtaining theoretical values of the Grubel-Lloyd index beyond the acceptable interval [0;1]. All explanatory variables, except for dummy ones, were logarithmised. 


\section{Theoretical Hypotheses}

The following research hypotheses concerning the intensity of intraindustry trade between Poland and European Union member states were subject to verification:

$\mathrm{H}_{1}$ : There is a positive correlation between the size of the economies of trading partners, measured by the size of their GDP, and the intensity of intra-industry trade with these countries.

$\mathrm{H}_{2}$ : There is a negative correlation between relative differences in the size of the economies of trading partners (measured by the size of their GDP) and the intensity of intra-industry trade between these countries.

$\mathrm{H}_{3}$ : The intensity of intra-industry trade in Poland's bilateral trade turnover is correlated with the level of saturation of the trading partner's economy with foreign capital, but the direction of this dependence is not clearly defined.

$\mathrm{H}_{4}$ : There is a positive correlation between the share of processed products in bilateral trade turnover between Poland and EU member states and the intensity of their mutual intra-industry trade.

$\mathrm{H}_{5}$ : There is a negative correlation between the degree of trade imbalance between trading partners and the intensity of their mutual intra-industry trade.

$\mathrm{H}_{6}$ : There is a positive correlation between the intensity of trade between countries measured by the share of a particular trading partner in Poland's total trade turnover and the intensity of their mutual intra-industry trade.

$\mathrm{H}_{7}$ : A similar language, which is an official language in the countries that trade with Poland, belonging to the group of Slavic languages, significantly increases the intensity of mutual intra-industry trade.

$\mathrm{H}_{8}$ : There is a negative correlation between the geographical distance, which divides trading partners and the intensity of their mutual intraindustry trade.

$\mathrm{H}_{9}$ : EU membership significantly increases the intensity of intra-industry trade.

\section{Model Estimation}

The theoretical hypotheses allowed the model specification for panel data to be obtained: 


$$
\begin{gathered}
I I T_{j t}=\alpha_{0}+\alpha_{1} G D P_{j t}+\alpha_{2} D G D P_{j t}+\alpha_{3} F D I_{j t}+\alpha_{4} M A N U F_{j t}+ \\
+\alpha_{5} T I M B_{j t}+\alpha_{6} T I_{j t}+\alpha_{7} L A N G_{j}+\alpha_{8} D I S T_{j}+\alpha_{9} U E_{j t}+v_{j t} \\
v_{j t}=e_{t}+u_{j}+\varepsilon_{j t}
\end{gathered}
$$

The description of the variables and sources of data used are shown in

\begin{tabular}{|c|c|}
\hline Variable & Variables description \\
\hline$I I T_{j t}$ & $\begin{array}{l}\text { The intensity of intra-industry trade between Poland and the } \\
\text { country } j \text { in the time period } t \text {, measured by the Grubel-Lloyd } \\
\text { index. } \\
\text { Data source: United Nations (2014). UN Comtrade Database. }\end{array}$ \\
\hline$G D P_{j t}$ & $\begin{array}{l}\text { Gross Domestic Product of the partner country } j \text {, in the time peri- } \\
\text { od } t \text {. } \\
\text { Data source: The World Bank (2014). World Development Indi- } \\
\text { cators. }\end{array}$ \\
\hline \multirow[t]{6}{*}{$\overline{D G D P_{j t}}$} & $\begin{array}{l}\text { The index of the relative difference in the size of Poland's GDP } \\
\text { and GDP of the partner country } j \text {, in the time period } t \text {. The index } \\
\text { values are measured by means of the following formula (cf., for } \\
\text { instance, Zhang and Li, 2006): }\end{array}$ \\
\hline & $D G D P_{j t}=1+\frac{[w \ln w+(1-w) \ln (1-w)]}{\ln 2}$, \\
\hline & $w=\frac{G D P_{P L t}}{G D P_{P L t}+G D P_{j t}}$ \\
\hline & where: \\
\hline & $\begin{array}{l}G D P_{P L t}, G D P_{j t} \text { - the size of Poland's GDP and GDP of the part- } \\
\text { ner country } j \text { in the time period } t \text {. }\end{array}$ \\
\hline & $\begin{array}{l}\text { The above index takes on values from the interval }[0 ; 1] \text {. If the } \\
\text { differences in GDP between countries are large, then the index } \\
\text { approaches the value of } 1 \text {. When GDP is identical for both coun- } \\
\text { tries, then it equalizes } 0 \text {. }\end{array}$ \\
\hline
\end{tabular}
Table. 1.

Table 1. Variables used in empirical investigation 
Table 1 continued

\begin{tabular}{|c|c|}
\hline Variable & $\begin{array}{l}\text { Variables description } \\
\end{array}$ \\
\hline$F D I_{j t}$ & $\begin{array}{l}\text { Capital resources in a form of foreign direct investments which } \\
\text { flew into the partner country } j \text { from } 1993 \text { to the year } t \text {. } \\
\text { Data source: United Nations Conference on Trade and Develop- } \\
\text { ment (2013). World Investment Report. }\end{array}$ \\
\hline$M A N U F_{j t}$ & $\begin{array}{l}\text { The share of processed products in total trade volume with the } \\
\text { trading partner } j \text { in the year } t \text {. }\end{array}$ \\
\hline$E U_{j t}$ & $\begin{array}{l}\text { The dummy variable takes on the value } 1 \text {, if in the year } t \text {, Poland } \\
\text { and its trading partner } j \text { were EU member states, and takes the } \\
\text { value } 0 \text {, if the two countries, or one of them, did not belong to the } \\
\text { European Union. }\end{array}$ \\
\hline$T I M B_{j t}$ & $\begin{array}{l}\text { The degree of trade imbalance of trade exchange between Poland } \\
\text { and the country } j \text {, in the year } t \text {. The variable was designated as the } \\
\text { share of the trade balance with the partner } j \text { in total turnover. } \\
\text { Data source: United Nations (2014). UN Comtrade Database. }\end{array}$ \\
\hline$T I_{j t}$ & $\begin{array}{l}\text { The share of the country } j \text { in Poland's total trade turnover in the } \\
\text { year } t \text {. } \\
\text { Data source: United Nations (2014). UN Comtrade Database }\end{array}$ \\
\hline$L A N G_{j}$ & $\begin{array}{l}\text { The dummy variable takes on the value 1, when the language of } \\
\text { Poland's trading partner belongs to the Slavic languages group, } \\
\text { and equals } 0 \text {, when it does not belong to the Slavic languages } \\
\text { group. }\end{array}$ \\
\hline$D I S T_{j}$ & $\begin{array}{l}\text { The geographical distance between the capitals of Poland and its } \\
\text { trading partner } j \text {. } \\
\text { Data source: Centre D'Etudes Prospectives et D'Informations } \\
\text { Internationales (2014). GeoDist. }\end{array}$ \\
\hline$v_{j t}$ & $\begin{array}{l}\text { The random error in the object } j \text {, in the time period } t \text {, which con- } \\
\text { sists of the following components: } \\
e_{t}-\text { impulses affecting all observations in the time period } t \text {, } \\
u_{j}-\text { impulses affecting all the observations in the object } j \text {, } \\
\varepsilon_{j t}-\text { impulses affecting only observations in the object } j \text {, in the } \\
\text { time period } t \text {. }\end{array}$ \\
\hline
\end{tabular}

Source: elaborated by the author.

\section{Results}

The estimation of the panel data model, designated with formula (2) was made with the use of the Gretl (GNU Regression Econometrics Time-Series Library) software, version 9.1.14. There were no a priori assumptions made for the occurrence and significance of individual effects, as well as 
for the character of the individual effects (fixed or random). The choice of the estimation methods (pooled OLS, fixed effects, random effects) was made with the use of a decision procedure from the field of econometrics advocated in the literature (see, for instance: Baltagi, 2001; Muszyńska 2006, pp. 213-236). The model is estimated with the use of a least squares method and diagnostic tests were performed and as a result the following values of the test statistics were obtained: the Wald test $(\mathrm{F}=6.248$; $\mathrm{p}$ value $<0.00001)$ the Breusch-Pagan test $(\mathrm{LM}=91.852$; p-value $<0.00001)$ and the Hausman test $(\mathrm{H}=16.319$; $\mathrm{p}$-value $=0.00262)$.

Based on the diagnostic tests conducted, it was found that a suitable model to study the impact of the macroeconomic determinants of the intensity of intra-industry trade is the model with fixed effects $(F E)$. Therefore, the model parameters with fixed effects were estimated. However, the phenomenon of heteroscedasticity occurred, that is the non-homogeneity of the random components variance within the sample. Heteroscedasticity affects inappropriate estimations of standard errors for individual parameters and the revaluation of the coefficient of determination, which may distort the conclusions regarding the significance of variables. Therefore, to estimate the parameters ultimately, the weighted least-squares method was applied $(W L S)$.

Statistical values of significant parameters of the model described by formula (2) are shown in Table 2.

The above model is statistically correct. Eight out of the nine potential explanatory variables proved to be significant. In the model all of the obtained signs for parameter estimates for a particular explanatory variable are consistent with the predictions of the theory. The general performance of the model is satisfactory (Adjusted $\mathrm{R}^{2}=0.72$ ).

When interpreting the results obtained in relation to the variables that were previously logarithmised, the following interpretation method can be used: the increase in the explanatory variable by $1 \%$, causes ceteris paribus an increase or decrease (depending on the sign of the parameter) in the dependent variable of $\alpha \%$ (the parameter for a specific explanatory variable). In this case, the dependent variable is the logit, which means that the relation $I I T_{j l} / 1-I I T_{j t}$, changes by $\alpha \%$, which is the relation of intra-industry trade $\left(I I T_{j t}\right)$ and inter-industry trade $\left(1-I I T_{j t}\right)$. 
Table 2. Results of the estimation of the model describing Poland's intra-industry trade with the use of the country-specific determinants

\begin{tabular}{|c|c|c|c|c|c|}
\hline \multicolumn{6}{|c|}{ Dependent variable $\ln \left(I I T_{j t} / 1-I I T_{j t}\right)$} \\
\hline $\begin{array}{l}\text { Independent } \\
\text { variables }\end{array}$ & Coefficient & $\begin{array}{l}\text { Std. } \\
\text { Error }\end{array}$ & $t$-ratio & p-value & Significance $^{a)}$ \\
\hline Constant & -1.7837 & 0.9372 & -1.903 & 0.0582 & $*$ \\
\hline$M A N U F_{i t}$ & 0.8443 & 0.2108 & 4.005 & $<0.00001$ & $* * *$ \\
\hline$T I M B_{j t}$ & -0.0435 & 0.0121 & -3.603 & 0.0004 & $* * *$ \\
\hline$T I_{j t}$ & 0.1574 & 0.0421 & 3.742 & 0.0002 & $* * *$ \\
\hline$G D P_{j t}$ & 0.1143 & 0.0409 & 2.799 & 0.0055 & $* * *$ \\
\hline$D G D P_{j t}$ & -0.0134 & 0.0074 & -1.816 & 0.0705 & $*$ \\
\hline$L A N G_{j}$ & 0.4350 & 0.0668 & 6.508 & $<0.00001$ & $* * *$ \\
\hline$U E_{j t}$ & 0.1576 & 0.0415 & 3.795 & 0.0002 & $* * *$ \\
\hline$D I S T_{j}$ & -0.1931 & 0.0660 & -2.925 & 0.0038 & $* * *$ \\
\hline \multicolumn{2}{|c|}{ Observations } & \multicolumn{4}{|c|}{260} \\
\hline \multicolumn{2}{|c|}{ Standard error of residuals } & \multicolumn{4}{|c|}{0.903540} \\
\hline \multicolumn{2}{|c|}{$\mathrm{R}^{2}$} & \multicolumn{4}{|c|}{0.726752} \\
\hline \multicolumn{2}{|c|}{ Adjusted $\mathrm{R}^{2}$} & \multicolumn{4}{|c|}{0.718043} \\
\hline \multicolumn{2}{|c|}{$\mathrm{F}(8,251)=83.44733$} & \multicolumn{4}{|c|}{$\mathrm{p}$-value for test $\mathrm{F}<0.00001$} \\
\hline
\end{tabular}

Source: the author's own calculations.

The results of the research confirm that the factor that significantly and at the same time positively effects the growth of the intra-industry trade indices is the share of processed products in mutual trade exchange. The resulting value of the parameter $\alpha$ for the variable $M A N U F_{j t}$ informs that the average increase in the share of processed products in trade exchange between countries by $1 \%$, causes a slightly smaller than the proportional (because almost by $0.8 \%$ ) increase in intra-industry trade relative to interindustry trade. The research hypothesis $\mathrm{H}_{4}$ was verified positively.

The degree of the intensity of trade between Poland and its trading partners (variable $T I_{j t}$ ) is also significant. The intensity of trade was expressed as the share of individual trading partners in Poland's total trade turnover. The impact strength of this factor, however, is smaller, as indicated by the parameter $\alpha$, for the variable $T I_{j t}$, which is 0.16 . The research hypothesis $\mathrm{H}_{6}$ was verified positively.

A factor that significantly but the same time negatively affects the intensity of intra-industry trade is also the degree of trade imbalance between Poland and EU countries. The value of the parameter $\alpha$ of the variable $T I M B_{j t}$ was -0.04 . The hypothesis $\mathrm{H}_{5}$ was verified positively. 
Statistically significant, though of a smaller impact strength, proved to be the determinants describing the size of the trading partners' economies. The study confirms that the size of a trading partner, measured with its GDP, has a positive impact on the intensity of intra-industry trade $(\alpha=0.11)$. However, increases in the size of trading partners' GDP (the variable $\left.D G D P_{j t}\right)$ has a negative impact on the intensity of this bilateral exchange $(\alpha=-0.01)$. With respect to these variables $\left(G D P_{j t}, D G D P_{j t}\right)$ the signs obtained were consistent with the predictions of the theory, which led to a positive verification of the research hypotheses $\mathrm{H}_{1}$ and $\mathrm{H}_{2}$.

An important factor determining the intensity of intra-industry trade turned out to be the geographical distance. The study confirmed the prediction of the theory that the smaller the distance between trading partners, the more intense the mutual intra-industry trade exchange. Therefore, the research hypothesis $\mathrm{H}_{8}$ was given a positive verification.

Within the estimated model two dummy variables proved to be statistically significant. One of them $\left(E U_{j t}\right)$ is related to Poland's and its trading partners' EU membership. This variable had the value of 1 in the years when Poland and its trading partner were members of the European Union, and had the value of 0 when one of the countries (Poland, or its trading partner) or both countries (Poland and its trading partner) did not belong to the EU. The other variable $\left(L A N G_{j}\right)$ describes the cultural ties of trading partners, expressed by the affiliation of the trading partner's language to the Slavic language group. In the case of the dummy variables $U E_{j t}$ and $L A N G_{j}$ based on the evaluation of the sign of the parameter estimate for a particular explanatory variable, one can specify only the direction of the impact of this variable on the dependent variable. A positive relationship between partners' EU membership and the intensity of their mutual intra-industry trade can be inferred from the obtained results. The positive impact on the intensity of bilateral trade also occurs when the population of a country being Poland's trading partner uses as their primary language a language belonging to the Slavic group. The results obtained are consistent with the predictions of theory and allow the positive verification of the research hypotheses $\mathrm{H}_{7}$ and $\mathrm{H}_{9}$.

The variables $F D I_{j t}$ proved to be statistically insignificant. Therefore, the research hypotheses $\mathrm{H}_{3}$, concerning the impact of foreign direct investment on the intensity of intra-industry trade, failed to be verified. 


\section{Conclusions}

Intra-industry trade that consists in simultaneous importing and exporting similar products belonging to the same industry plays an increasingly important role in Poland's trade with European Union member states. This type of exchange is conditioned by numerous and various factors. The focus was on the features of the economies of the countries participating in that exchange that is on the country-specific determinants. The paper presents the identification of the factors determining the type of intra-industry trade between Poland and EU member states.

As follows from the study, a positive impact on the development of intra-industry trade is exerted by the share of processed products in Poland's bilateral trade with EU member states and the intensity of trade with those countries. The determinants related to the size of the economies of trading partners proved to be statistically significant. The study confirmed that the size of the trading partner, measured by the size of its GDP, influences positively the intensity of intra-industry trade, while increases in differences in the size of the GDP of trading countries has a negative impact on the intensity of bilateral exchange.

The development of intra-industry volume is also favoured by EU membership and the by fact that Poland's trade partners use a similar language, which belongs to the Slavic languages group. An adverse effect on the intensity of intra-industry trade is exerted by the degree of trade imbalance between trading partners and the geographical distance separating the trading countries. The study confirmed that the impact of all of the identified determinants of intra-industry trade is consistent with the predictions of the theory.

\section{References}

Balassa, B., \& Bauwens, L. (1988). The Determinants of Intra-European Trade in Manufactured Goods. European Economic Review, 32(7). DOI: http://dx.doi.org/10.1016/0014-2921(88)90109-2.

Baltagi, B. H. (2001). Econometric Analysis of Panel Data, Chichester: John Wiley $\&$ Sons.

Byun, J. J., \& Lee, S.-H. (2005). Horizontal and Vertical Intra-Industry Trade: New Evidence from Korea, 1991-1999. Global Economy Journal, 5(1). DOI: http://dx.doi.org/10.2202/1524-5861.1036.

Centre D'Etudes Prospectives et D'Informations Internationales (2014). GeoDist. Retrieved from http://www.cepii.fr/anglaisgraph/bdd/distances.htm. (December 2014). 
Černoša, S. (2002). Vnitroodvětvový obchod a vliv rozdílů ve velikosti zemí - na př́padu Slovinska a České republiky. Finance a úvěr, 52(6).

Cieślik, A. (2000). Nowa teoria handlu zagranicznego w świetle badań empirycznych, Warszawa: Wydawnictwo Naukowe PWN.

Ekanayake, E. M. (2001). Determinants of Intra-Industry Trade: The Case of Mexico. International Trade Journal, 15(1). DOI: http://dx.doi.org/10.1080 1088539001300005468.

Fitzová, H., \& Žídek, L. (2015). Impact of Trade on Economic Growth in the Czech and Slovak Republics. Economics and Sociology, 8(2). DOI: 10.14254/2071-789X.2015/8-2/4.

Foster, N., \& Stehrer, R. (2011). Preferential Trade Agreements and the Structure of International Trade. Review of World Economics, 147(3). DOI: http://dx.doi.org/10.1007/s10290-011-0093-y.

Grubel, H. G., \& Lloyd, P. J. (1975). Intra-Industry Trade: The Theory and Measurement of International Trade in Differentiated Products. London: Macmillan.

Kim, T., \& Oh, K.-Y. (2001). Country Size, Income Level and Intra-Industry Trade. Applied Economics, 33(3). DOI: http://dx.doi.org/10.1080/00036840122 211.

Leitão, N. C. (2011). Intra-industry Trade in the Agriculture Sector: The Experience of United States. African Journal of Agricultural Research, 6(1). DOI: http://dx.doi.org/10.5897/AJAR10.822.

Leitão, N. C., \& Shahbaz, M. (2012). Liberalization and United States' IntraIndustry Trade. International Journal of Economics and Financial Issues, 2(4).

Loertscher, R., \& Wolter, F. (1980). Determinants of Intra-Industry Trade: Among Countries and Across Industries. Weltwirtschaftliches Archiv, 116(2).

Markusen, J. R., \& Vanables, A. J. (1996). The Theory of Endowment, IntraIndustry and Multinational Trade. Retrieved from http://www.nber.org/papers/ w5529.pdf?new_window=1 (1.04.2015).

Muszyńska, J. (2006). Modelowanie danych panelowych. Zeszyty Naukowe Państwowej Wyższej Szkoły Zawodowej we Wtocławku, 1.

Salamaga, M. (2012). Ocena wpływu bezpośrednich inwestycji zagranicznych na handel wewnątrzgałęziowy w wybranych krajach Europy ŚrodkowoWschodniej. Zeszyty Naukowe Uniwersytetu Ekonomicznego w Krakowie, 878.

Sharma, K. (2004). Horizontal and Vertical Intra-industry Trade in Australian manufacturing: Does Trade Liberalization Have any Impact? Applied Economics, 36. DOI: http://dx.doi.org/10.1080/0003684042000218534.

Stone, J. A., \& Lee, H.-H. (1995). Determinants of Intra-Industry Trade: A Longitudinal, Cross-Country Analysis. Weltwirtschaftliches Archiv, 131(1). DOI: http://dx.doi.org/10.1007/BF02709072.

The World Bank (2014). World Development Indicators. Retrieved from http://data.worldbank.org/data-catalog/world-development-indicators. (December 2014).

Thorpe, M., \& Zhang, Z. (2005). Study of the Measurement and Determinants of Intra-Industry Trade in East Asia. Asian Economic Journal, 19(2). DOI: http://dx.doi.org/10.1111/j.1467-8381.2005.00211.x. 
United Nations Conference on Trade and Development (2013). World Investment Report. Retrieved from http://unctad.org/en/pages/DIAE/World\%20Investm ent\%20Report/WIR-Series.aspx. (2.12.2014).

United Nations (2014). UN Comtrade Database. Retrieved from http://comtrade.un.org/data/. (2.12.2014).

Wakasugi, R. (2007). Vertical Intra-Industry Trade and Economic Integration in East Asia. Asian Economic Papers, 6(1). DOI: http://dx.doi.org/10.1162 lasep.2007.6.1.26.

Xing, Y. (2007). Foreign direct investment and China's bilateral intra-industry trade with Japan and the US. Journal of Asian Economics, 18(4). DOI: http://dx.doi.org/10.2139/ssrn.1002290.

Zhang, Y., \& Clark, D. P. (2009). Pattern and Determinants of United States' IntraIndustry Trade. International Trade Journal, 23(3). DOI: http://dx.doi.org/10 $.1080 / 08853900903012310$.

Zhang, Z., \& Li, C. (2006). Country-Specific Factors and the Pattern of IntraIndustry Trade in China's Manufacturing. Journal of International Development, 18. DOI: http://dx.doi.org/DOI: 10.1002/jid.1288.

Zielińska-Głębocka, A. (1991). Teorie międzynarodowej specjalizacji wewnątrzgatęziowej $i$ handlu towarami przemystowymi między krajami uprzemystowionymi. Gdańsk: Wydawnictwo Uniwersytetu Gdańskiego. 